\title{
Occurrence and significance of ovarian and follicular regression in cachara Pseudoplatystoma fasciatum (Linnaeus, 1766): a histology approach
}

\author{
[Ocorrência e importância da regressão ovariana e folicular em cacharas, Pseudoplatystoma \\ fasciatum (Linnaeus, 1766): enfoque histológico]
}

\author{
A.F.G. Leonardo ${ }^{1}$, E. Romagosa ${ }^{2}$, S.R. Batlouni ${ }^{3}$, M.I. Borella ${ }^{3}$ \\ ${ }^{1}$ Faculdade de Ciências Agrárias e Veterinárias - UNESP - Jaboticabal, SP \\ ${ }^{2}$ Instituto de Pesca - APTA \\ Avenida Francisco Matarazzo, 455 \\ 05001-900 - São Paulo, SP \\ ${ }^{3}$ Departamento de Biologia Molecular e Desenvolvimento - USP, SP
}

\begin{abstract}
The processes of ovarian regression and follicular atresia which reproduction was not induced by hormone in confined cachara, Pseudoplatystoma fasciatum, were investigated. The macro and microscopic characteristics (oocytes diameter and histology) of the ovaries were described every 20 days, in four stages: initial regression ( $\mathrm{Rg} I=$ first 20 days), intermediate regression $(\mathrm{Rg} I \mathrm{II}=$ from 21 st to 40 th day), final regression $(\mathrm{Rg} I I I=$ from 41 st to 80 th day) and the recovering stage, called resting II (R II = from 81 st to 150th day). The experiment was conducted from late January (summer - longer days) to May (autumn - shorter days). In the beginning, A0 samples showed oocyte diameters ranging from 437.5 to $1,187.5 \mu \mathrm{m}$, suggesting that oocytes were in perinucleolar, at final maturation and atretic phases. After 150 days, the diameters reached the lowest values and a ruptured zona radiata, as well as the nearly complete reabsorption of the yolk could be visualized. At the same time, a sharp decrease in the mean values of the gonadosomatic index (GSI), water temperature, photophase and rainfall was observed. The gradual involution of this long process was dynamic and complex, affecting the spawning success (fertilization, eclosion and larvae survival rates) and, consequently, the whole productive system.
\end{abstract}

Keywords: cachara, Pseudoplatystoma fasciatum, ovarian regression, atretic follicle, histology

\section{RESUMO}

Estudaram-se os processos de regressão ovariana e atresia folicular em cachara, Pseudoplatystoma fasciatum, mantida em cativeiro, na reprodução não induzida por hormônios. As características macro e microscópicas (diâmetro dos ovócitos e histologia) dos ovários foram descritas a cada 20 dias, em quatro estádios: na regressão inicial (Rg I - os primeiros 20 dias), na regressão intermediária (Rg II - do $21^{\circ}$ ao $40^{\circ}$ dia), na regressão final (Rg III - do $41^{\circ}$ ao $80^{\circ}$ dia) e na fase de recuperação ou de repouso II ( $R$ II - do $81^{\circ}$ ao $150^{\circ}$ dia). O experimento foi realizado do final de janeiro (verão-dias longos) a maio (outono-dias curtos). No início do experimento, as amostras apresentaram ovócitos com diâmetros que variaram de 437,5 a 1.187,5 $\mu$ m, sugerindo encontrarem-se nas fases perinucleolar, de maturação final e atrésicos. Aos 150 dias, os diâmetros atingiram os menores valores e pôde-se visualizar a zona radiata rompida e o vitelo reabsorvido. Concomitantemente, houve diminuição abrupta dos valores médios do indice gonadossomático, da temperatura da água, das horas de luz e de chuva. A involução gradual do

Recebido em 30 de agosto de 2004

Aceito em 2 de dezembro de 2005

*Autor para correspondência ( corresponding author)

E-mail: eromagosa@pesca.sp.gov.br 
longo processo foi dinâmica e complexa, afetando o êxito da desova (taxas de fertilização, de eclosão e de sobrevivência de larvas) e, conseqüentemente, o sistema produtivo.

Palavras-chave: cachara, Pseudoplatystoma fasciatum, regressão ovariana, folículo atrésico, histologia

\section{INTRODUCTION}

The Pseudoplatystoma fasciatum is one of the most important commercial Pimelodidae of the Brazilian Southeastern. Nearly $30 \%$ of all the Brazilian freshwater fish are Siluriformes (Britski et al., 1984), which includes some important commercial fish, accounting for about $65 \%$ of the wild harvested Siluriformes (IBGE, 1998). This kind of fish can be found in the main South American river systems, such as São Francisco, Amazon as and Prata (Fowler, 1951).

$P$. fasciatum performs long migrations, breeding in the spring and summer seasons from November to January, when rainfall and water temperature reach their highest values (Resende et al., 1995). This catfish has attractive zootechnical and market patterns (Romagosa et al., 2003).

When kept in confinement and not induced to breed, ovaries of $P$. fasciatum start the process of degeneration (Miranda et al., 1995; Romagosa, 1998; Romagosa et al., 2001). The same was also observed by Resende et al. (1995) in wild individuals of the same species.

According to Munro (1990), South American Siluriformes spawn mainly in flooded areas, do not manifest parental care and the final maturation of the gonads is completed (approximately two months), before the end of the rainy season. The same author states that high temperatures inhibit steroid synthesis, acting like a biological buffer in the reproductive process, leading the gonads to regression. The author claims that temperature can also influence the metabolic activity and the fish growth.

The process of ovarian degeneration may affect the reproductive performance in fish, especially concerning fertilization and hatching rates (Romagosa et al., 2001; Zohar and Mylonas, 2001; Zaniboni Filho and Nuñer, 2004).

The purpose of this study was to investigate the processes of ovarian regression and follicular atresia in confined cachara, $P$. fasciatum, which were undergoing first ovarian maturation.

\section{MATERIAL AND METHODS}

This study was carried out at the Fishery Department of Pólo Regional Desenvolvimento Sustentável do Vale do Ribeira - APTA, in the city of Pariquera-Açu, São Paulo. Thirty females $P$. fasciatum (Linnaeus, 1766) coming from induced spawning cultured fish (private companies) averaging $1.94 \mathrm{~kg} \pm 0.27 \mathrm{~kg}$ weight and $63.5 \pm 1.5 \mathrm{~cm}$ length, were kept in two $200 \mathrm{~m}^{2}$ ponds, $1.50 \mathrm{~m}$ mean depth, $181 / \mathrm{min}$. outflow, for two years and seven months (date of the first ovarian maturation).

The fish were fed on a commercial feed containing $40 \%$ crude protein, twice a day, at 8.00 a.m. and 5.00 p.m., seven days a week, at a rate of $5 \%$ of total body weight during the warm months (September to February) and 1.5\% during the cold months (March to August).

Initially, all the 30 females were sampled (sample A0) using the catheter technique, according to the method described by Romagosa et al. (2002), in order to determine the stage of ovarian maturation. Five females of this group were killed and had their ovaries were removed and sampled for histological studies (sample A0). The remaining 25 females were individually marked with coloured thread at the top of the dorsal fin and put back in their ponds. In the subsequent sampling (A1, A2, A3, A4 e A5), it was not possible to obtain samples of oocytes using the catheterization technique (plastic catheter) because ovarian regression was already going on. Therefore, during the five following months, at every 20 days, five of these females were captured, anaesthetised ( $2 \mathrm{~g}$ benzocaine ethylaminobenzoate: $150 \mathrm{ml}$ alcohol: 201 water), weighed, killed by decapitation and dissected. Their ovaries, after being removed, were examined for weight (g), volume, vascularization and colour of oocytes. 
Fragments of ovaries were collected and fixed in Bouin's fluid for six hours, being afterwards dehydrated and embedded in glycol-methacrylate (Myhre and De Paoli, 1985), sectioned at 3-5 $\mu \mathrm{m}$ thin and stained with hematoxylin-eosine and toluidine blue-1\% sodium borate. The obtained slides were analysed and photographed.

The gonadosomatic index (GSI) was calculated based on the relation between ovary weight and total body weight of each animal, multiplied by 100. The efficiency of this index was individually verified through the linear relation between the former parameters. Comparisons were made between the values of GSI and the abiotic parameters - water temperature, hours of sunlight and rainfall during the experiment.

The average water temperature $\left( \pm 0.1^{\circ} \mathrm{C}\right)$ in the external ponds was measured twice a day at 8.00 a.m. and 5.00 p.m. Other parameters were also obtained for quality control, such as $\mathrm{pH}$, dissolved oxygen and ammonia. The means were compared by Tukey test at 5\% probability level.

\section{RESULTS}

In the beginning of the experiment, late January, 2001, all the 30 sampled females (A0) presented swollen abdomens and voluminous ovaries and slight signs of haemorrhage. Most oocytes were yellow, however, some rare white oocytes were found, revealing colour and shape heterogeneity. The distribution of oocyte diameter exhibited the same pattern, with polimodal tendency, with modes of 625.0, 937.5 and $1062.5 \mu \mathrm{m}$ (Fig. 1).

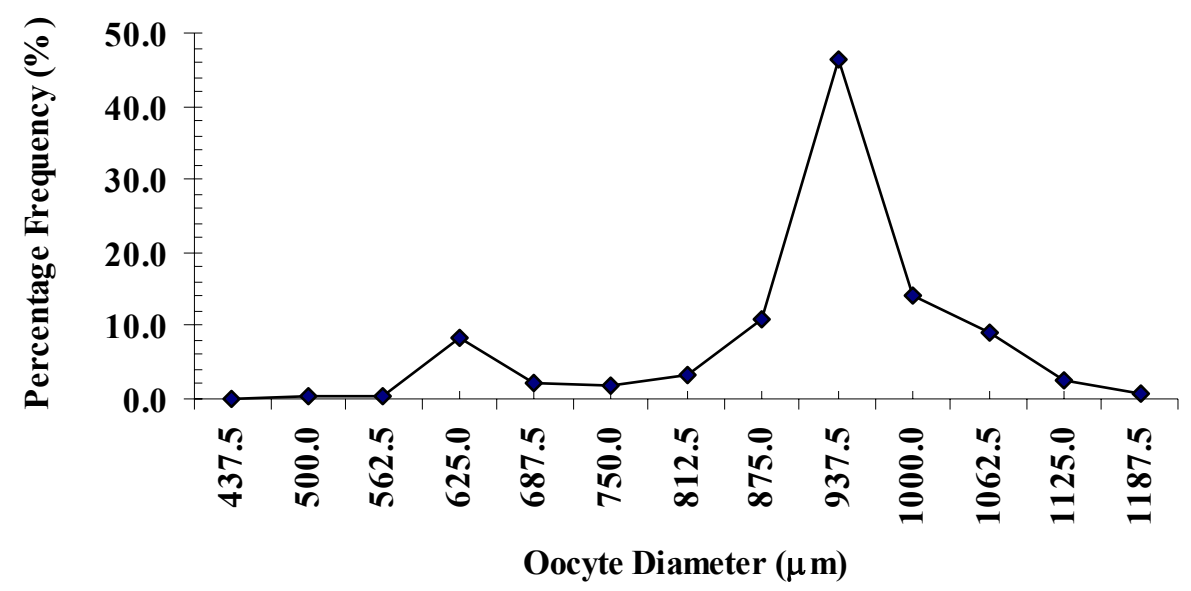

Figure 1. Oocyte diameter distribution in P. fasciatum - sample 0 (A0).

In sample A1 (Fig. 2A) it was macroscopically observed that the ovarian volume was reduced. The colour of the oocytes remained similar to the previous stage (A0), but white oocytes were more numerous and exhibited slight signs of haemorrhage and congestion (Fig. 2B), which is similar to the beginning of the ovarian regression described for Brycon cephalus by Romagosa et al. (2001). In sample A1 and in subsequent ones, it was not possible to collect sub-samples of the oocytes through the catheterization technique, due to the advanced stage of ovarian regression. Average ovarian weight ranged from 350.0 to 150.0g. Microscopically (Fig. 3A and 3B), oocytes at different stages of development were detected: perinucleolar, final maturation and atretic. Corrugation of the zona radiata, hypertrophy of the follicle cells and a few vacuoles in the ooplasm periphery were observed at this stage (Fig. 4A and 4B).

The five females from the third sample (A2) displayed yellow ovaries, which showed a large quantity of oocytes (Fig. 2B). However, a larger number of white oocytes was detected approximately $10 \%$ more than the number found in the previous stage. Ovary weight varied from 298.0 to $14.3 \mathrm{~g}$. Microscopically, it was observed that some of the oocytes had lost their round shape and showed a disorganization of nuclear 
and cytoplasmic (Fig. 3C). The nucleus, when visible, was slightly eccentric and a large quantity of yolk granules of different sizes could be seen in the cytoplasm. The follicle cells presented severe hypertrophy, penetrating
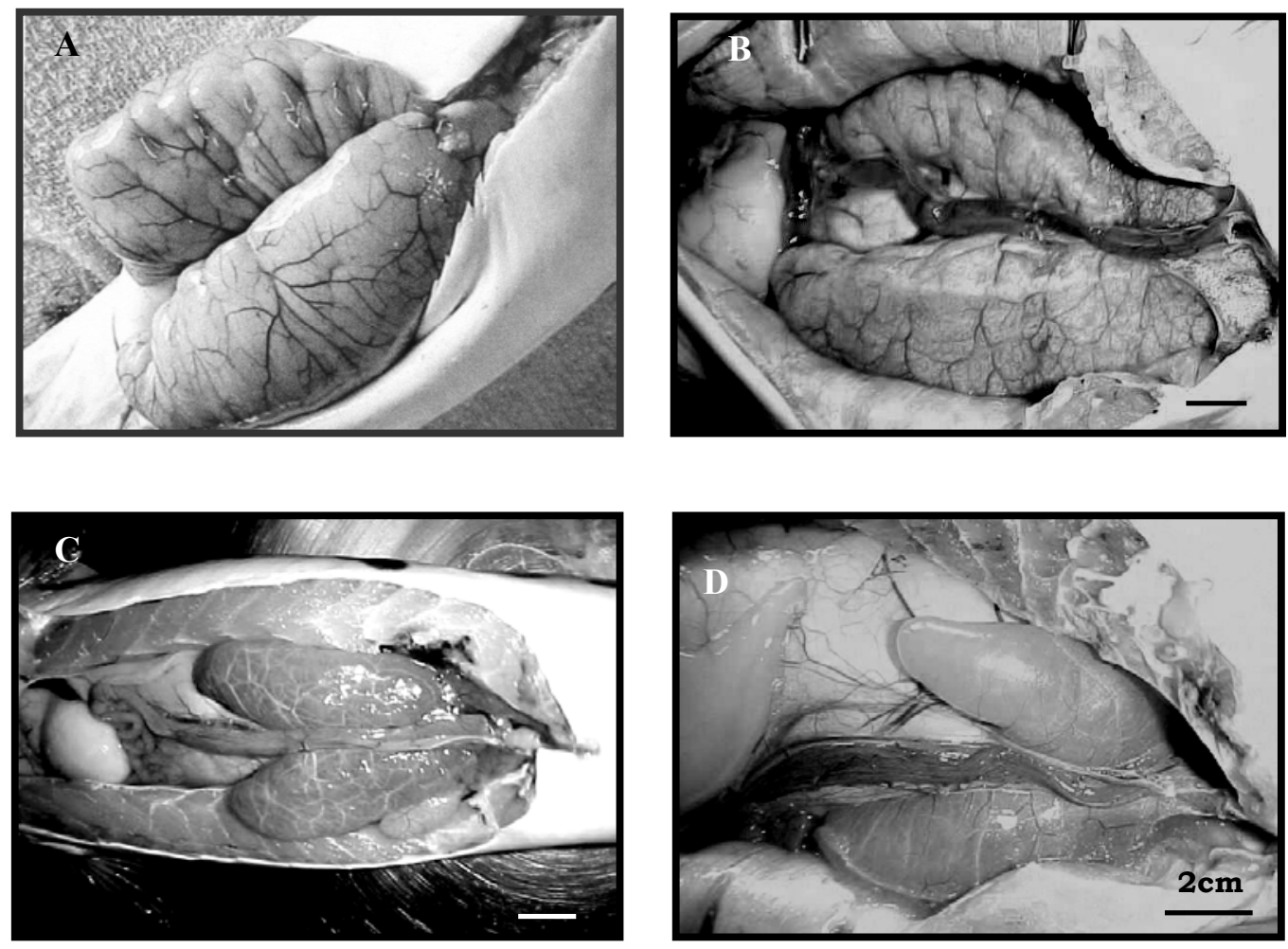

Figure 2. Ovaries of $P$. fasciatum. A) Voluminous with slight signs of haemorrhage; B) Reduced volume, highly vascularized and congested; C) Reduced size and brownish colour; D) Rosy taking up a little of the abdomen.

Sixty and 80 days after the beginning of the experiment (samples A3 and A4), the ovaries showed reduced volume, brown colour and were flabby, highly vascularized and quite congested (Fig. 2C). Microscopically, the ovaries exhibited large quantities of perinucleolar oocytes, but atretic oocytes were not so numerous (Fig. 3D). In the oocytes, the zona radiata was corrugated, ruptured or almost completely disintegrated (Figs 4C; 4D and 4E). The hypertrophied follicular cells gradually moved towards the oocytes' cytoplasm (Fig. 4E). The majority of the yolk granules had disintegrated, and only a small amount of yolk mass remained at the centre of the oocyte (Fig. 4E and 4F). This stage was towards the interior of the oocyte. The zona radiata became highly corrugated and ruptured, with radial wrinkles still visible. Yolk granules emerged among the follicle cells (Fig. 4C and 4D). 
marked structural evolution from day 20 to day 150, enabling the differentiation of four stages: regression I ( $\mathrm{Rg} \mathrm{I}=$ first 20 days); regression II $\left(\mathrm{Rg}\right.$ II $=$ from $21^{\text {st }}$ to $40^{\text {th }}$ day); regression III ( $\mathrm{Rg}$ $\mathrm{III}=$ from $41^{\text {st }}$ to $80^{\text {th }}$ day) and resting $(\mathrm{R}$ II $=$ from $81^{\text {st }}$ to $150^{\text {th }}$ day). Those stages occurred from late January to May, 2002. The Fig. 5 shows the three stages of regression, as well as the recovery phase (R II), which were concomitant with a decrease in the mean values of the gonadosomatic index (GSI), hours of light and rainfall during the period of the experiment (Tables 1 and 2).
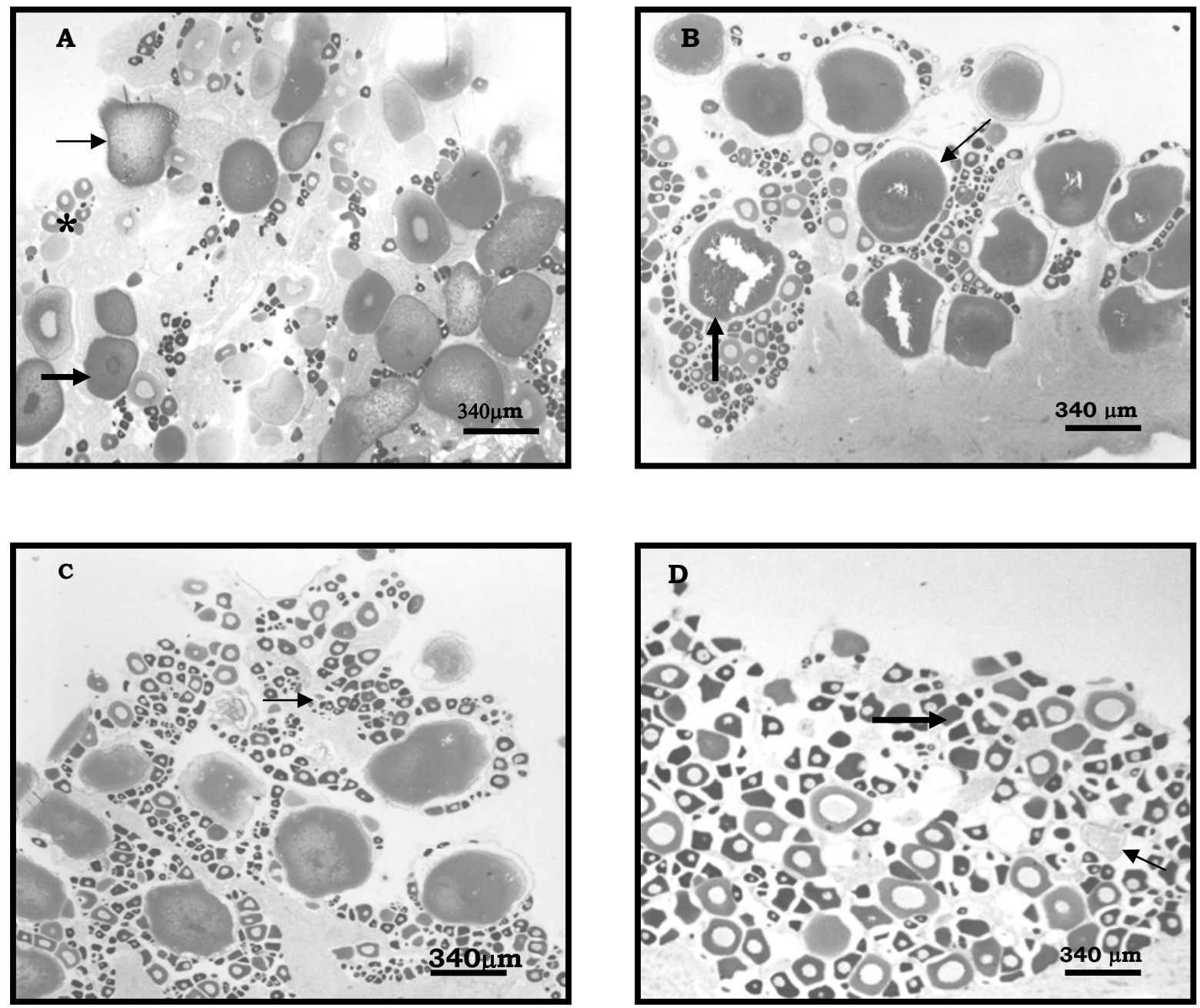

Figure 3. Ovaries of P. fasciatum. A) Perinucleolar oocyte $(*)$, oocytes at final maturation (fat arrow), oocytes at the beginning of follicular atresia (thin arrow); B) Large number of atretic oocytes (thin arrow), and some oocytes at perinucleolar stage (fat arrow); C) The number of atretic oocytes becomes lower that the number of perinucleolar oocytes (thin arrow); D) Vast majority of perinucleolar oocytes (fat arrow); oogonia (thin arrow). 

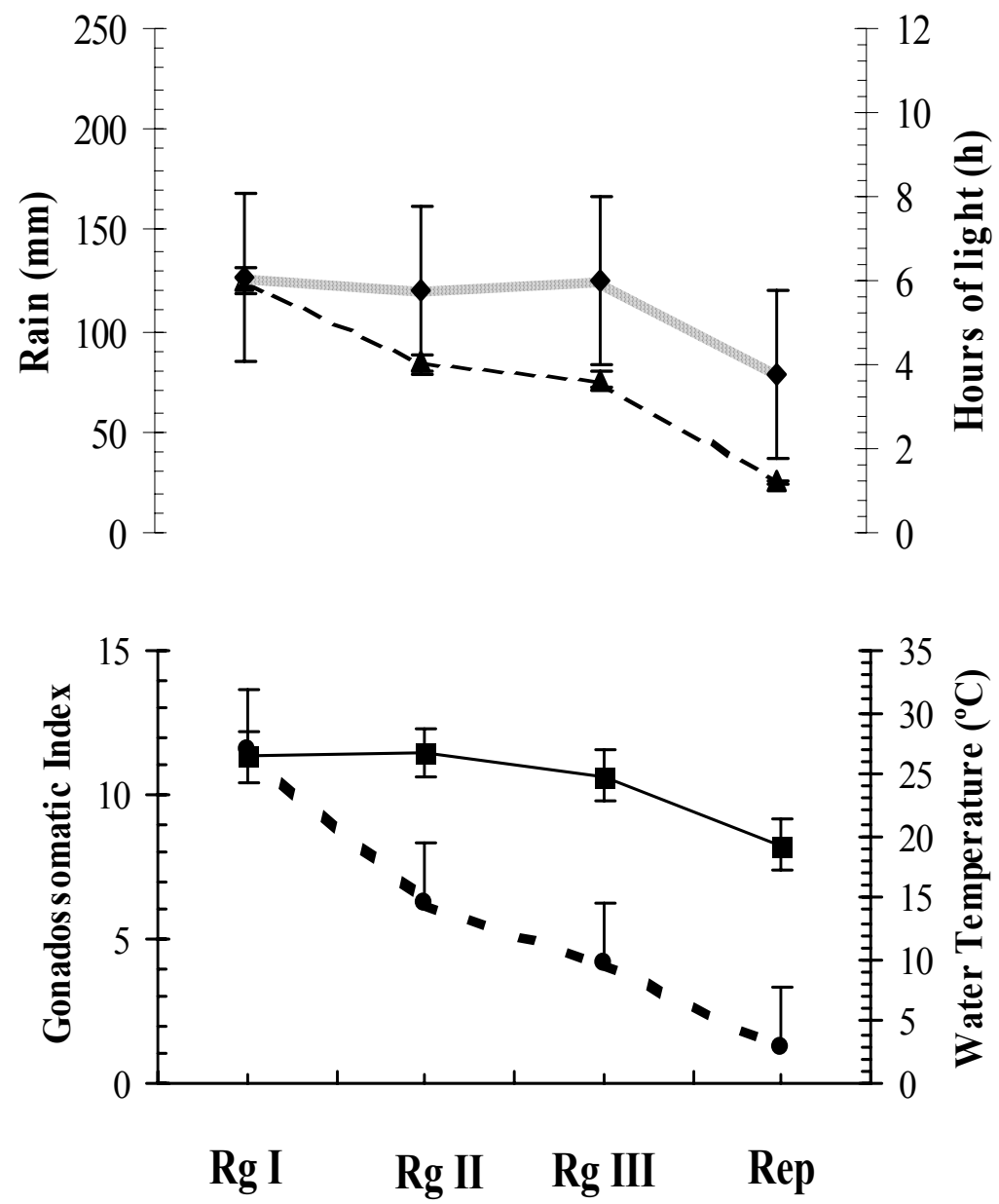

Figure 4. Stages of ovarian regression and recovery of $P$. fasciatum, in relation to GSI, water temperature, hours of light and rainfall (regression $=\mathrm{Rg}$; $\mathrm{Rg}$. I = first 20 days; $\mathrm{Rg}$. II $=$ from $21^{\text {st }}$ to $40^{\text {th }}$ day; $\mathrm{Rg}$. III $=$ from $41^{\text {st }}$ to $80^{\text {th }}$ day; resting II $=\mathrm{RII}=$ from $81^{\text {st }}$ to $150^{\text {th }}$ day).

Table 1. Stages of the average gonadosomatic index (GSI) of $P$. fasciatum

\begin{tabular}{lc}
\hline Stages & Gonadosomatic index (GSI) \\
\hline Rg I & $11.62 \pm 3.5 \mathrm{~A}$ \\
Rg II & $6.30 \pm 2,5 \mathrm{AB}$ \\
Rg III & $4.12 \pm 0.1 \mathrm{~B}$ \\
RII & $1.30 \pm 0.1 \mathrm{~B}$ \\
\hline The averages followed by the same letter do not differ \\
according to Tukey test $(\mathrm{P}>0.05)$.
\end{tabular}

Table 2. Stages of the GSI of $P$. fasciatum, temperature $\left({ }^{\circ} \mathrm{C}\right)$, rain $(\mathrm{mm})$ and hours of light (h) during January and May 2001

\begin{tabular}{lccc}
\hline Stages & $\begin{array}{c}\text { Temperature } \\
\left({ }^{\circ} \mathrm{C}\right)\end{array}$ & $\begin{array}{c}\text { Rain } \\
(\mathrm{mm})\end{array}$ & $\begin{array}{c}\text { Hours of } \\
\text { light } \\
(\mathrm{h})\end{array}$ \\
\hline $\mathrm{Rg} \mathrm{I}$ & $26,4 \mathrm{~A}$ & $124,4 \mathrm{~A}$ & $6,1 \mathrm{~A}$ \\
$\mathrm{Rg}$ II & $26,8 \mathrm{~A}$ & $84,3 \mathrm{~A}$ & $5,8 \mathrm{~A}$ \\
$\mathrm{Rg}$ III & $24,9 \mathrm{~A}$ & $75,9 \mathrm{~A}$ & $6,0 \mathrm{~A}$ \\
$\mathrm{RII}$ & $19,3 \mathrm{~B}$ & $25,0 \mathrm{~A}$ & $3,8 \mathrm{~A}$ \\
\hline \multicolumn{7}{l}{ The averages followed by the same letter do not differ }
\end{tabular}

according to Tukey test $(\mathrm{P}>0.05)$. 

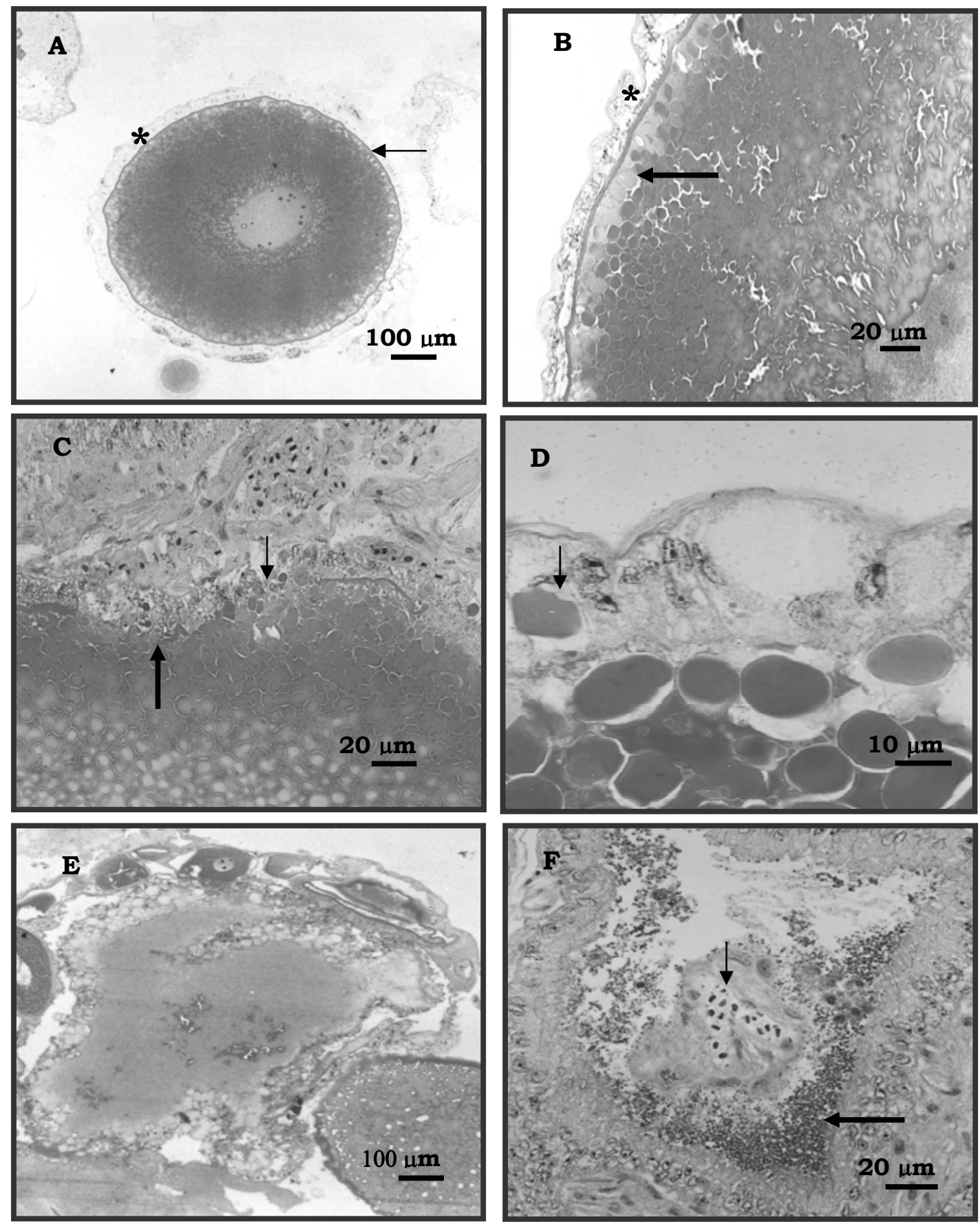

Figure 5. Ovaries of $P$. fasciatum. A) Oocyte at initial stage of atresia, displaying corrugated zona radiata (thin arrow) and hypertrophy of the follicle cells (*); B) Hypertrophy of the follicle cells $\left(^{*}\right)$, appearance of vacuoles at the ooplasm periphery (fat arrow); C) Ruptured zona radiata (thin arrow), hypertrophy and invagination of the follicle cells towards the centre of the oocyte (fat arrow); disorganisation of the yolk granules in the ooplasm (arrowhead); D) Theca cells (arrowhead) and follicular layer with yolk granules (thin arrow); E) Invagination of the follicle cells in the oocyte; F) Blood vessel inside the oocyte (fat arrow) and small portions of yolk granules (thin arrow). 


\section{DISCUSSION}

The process of ovarian regression in Pseudoplatystoma fasciatum was divided into three stages of regression ( $\mathrm{Rg}$ I, Rg II and Rg III) because they presented well-defined characteristics. The considered macroscopic aspects were size, colour, volume, vascularization and kind of oocyte in the ovaries. The examined microscopic factors were stage of the oocytes present in the ovaries, corrugation and rupture of zona radiata, hypertrophy of the follicular layer and its invagination, liquefaction and reabsorption, and presence of blood vessels. The same characteristics had been described by Romagosa (1998) e Romagosa et al. (2001) for Brycon cephalus.

With regard to the terms used in this paper, such as ovarian regression and follicular atresia, West (1990) stated that those terms had been referred to by previous authors as corpora atresica, preovulatory body, corpus luteum epithelial bodies etc. However, they were recently substituted by Shanbhag and Saidapur (1996) and Romagosa (1998) because no endocrine function has been detected in those structures.

Concerning the frequency distribution of oocyte diameter, initially all the females showed the same pattern of distribution, with polimodal tendency. Fenerich-Verani et al. (1984) and Romagosa et al. (2001), using oocyte diameter as an indicator of the degree of gonadal development for Prochilodus scrofa collected in the wild and induced to breed, noticed that the females which exhibited frequency distributions of oocyte diameter with modes higher than $1,100.00 \mu \mathrm{m}$ released oocytes, but they were not fertile. Our observations also coincide with the ones made by Romagosa et al. (2002) and Leonardo (2004) with P. fasciatum.

The morphological events are in accordance with the ones described for other Brazilian native freshwater species, such as Prochilodus scrofa, Prochilodus affinis, Pseudoplatystoma corruscans and Brycon cephalus (Bazzoli et al., 1988; Kunkel and Flores, 1996; Romagosa et al., 2001), with a similar profile of ovarian degeneration, involving volume decrease, colour alteration, increase in the number of white oocytes.
In Prochilodus scrofa, alterations in the follicular envelope are described - it becomes corrugated and folded in some areas - as well as the rupture of the zona radiata and progressive yolk disintegration. Yolk granules with yellowbrownish pigments, yellow bodies are also described in this species (Andrade-Talmelli et al., 1994). In Brycon cephalus and Astyanax bimaculatus lacustres (Romagosa et al., 2001; Miranda et al., 1999), these granules were not observed, probably because the process of yolk granule reabsorption is quite slow when compared to the one that occurs in P. scrofa. The same was observed in this $P$. fasciatum study.

The process of ovarian and follicular atresia in freshwater fish is a common phenomenon happening both in wildfish and confined fish (Guraya et al., 1975; Shanbhag and Saidapur, 1996); Romagosa et al., 2001). The according these authors, the process of degeneration can happen in fish at different stages of ovarian development (pre-spawning, spawning and postspawning). Apparently, stress is responsible for causing follicular atresia in captive fishes.

Several studies have been carried out on the effect of the interference of environmental components in the reproductive cycles of freshwater teleosts in tropical areas, with species deriving from natural habitats (Andrade-Talmelli et al., 1994) and confined (Romagosa et al., 1990; Romagosa, 1998; Andrade-Talmelli et al., 2002). In the course of the present experiment, the mean values of GSI fell $(\mathrm{Rg} I=11.6 \pm 3.5$; $\mathrm{Rg}$ $\mathrm{II}=6.1 \pm 2.5$ and $\mathrm{Rg}$ III $=1.3 \pm 0.1$ ), coinciding with the decrease in the mean values of water temperature, hours of sunlight and rainfall. Similarly, it was verified in Piaractus mesopotamicus that maturation (vitellogenesis and spermatogenesis) starts with the raise in hours of sunlight and water temperature (spring), and the values of GSI reach their peak in the summer, corresponding to the stage of advanced maturation for both sexes. Afterwards, ovarian and testicular reabsorption - period characterised by the decrease in the values of GSI - is triggered off (Iseki, 2002).

Lee and Yang (2002) studied Lateolabrax maculatus captured in the wild, under constant temperature and hours of sunlight, and observed that about $60 \%$ atretic follicles found in the 
ovaries under regression were related to the decrease in water temperature. The same could be observed in the present study, because when water temperature started to fall, the specimens used in the experiment began to show signs of ovarian regression.

In this study, the variation in ovary weight was smaller than the one observed in females of the same species captured in the wild (Resende et al., 1995). This is probably due to food management or some kind of physiological modification, such as stress, which can happen when the animals are confined (Romagosa et al., 2001). It is apparent that adverse environmental stress may induce ovarian follicular atresia and reduced fecundity in fishes in adverse conditions.

Ovarian regression occurred in $P$. fasciatum from January (summer - longer days) to May (autumn - shorter days). Final maturation took place when the mean values of water temperature reached $24.4 \pm 1.6^{\circ} \mathrm{C}$ at the beginning of the experiment (January). The first signs of ovarian and follicular atresia emerged at the end of January, coinciding with the fall in the values of water temperature, shorter days and decrease in the rainfall. The ovaries of the females of $P$. fasciatum underwent gradual transformations, until reaching the $\mathrm{R}$ II stage, re-starting the reproductive cycle again, in captivity.

The demand for good habitats for spawning, together with other characteristics of the biological behaviour must be considered to make the maintenance of the diversity of the species possible, predicting any kind of change in the Brazilian hydric system. The results of this study are of great importance, not only from the ecological point of view, but also for their application to fish farming and especially with regard to induced breeding. Nevertheless, Brazilian ichthyology diversity is considerably wide, and each group has its specific biological characteristics, thus requiring adjustments in the technical protocols, defining a technology which would be based on reliable parameters and on the use of accurate selection methods, considering the balance between cost and efficiency of spawning for juvenile production.

Future work should, therefore, be directed toward filling up the lacunae in our knowledge about the role of atretic follicles regression.
These findings would elucidate the status of this structure in the fish ovary.

\section{ACKNOWLEDGEMENTS}

The authors are grateful to Empresa de Pesquisa Agropecuária - Embrapa for supporting the project. The authors also wish to recognise the contribution made by Mr. Benedito Martins de Aguiar and Mr. Edilberto Rufino de Almeida of Pólo Regional (APTA) in the town of PariqueraAçu, São Paulo - Brazil.

\section{REFERENCES}

ANDRADE-TALMELLI, E.F.; KAVAMOTO, E.T.; NARAHARA, M.Y. et al. Reprodução induzida da piabanha, Brycon insignis, (Steindachner, 1876) (Characiformes, Bryconinae), mantida em confinamento. Rev. Bras. Zootec., v.31, p.803-811, 2002.

ANDRADE-TALMELLI, E.F; NARAHARA, M.Y.; ROMAGOSA, E. et al. Fases de degeneração ovocitária em Curimbatá, Prochilodus scrofa (STEINDACHNER, 1881), mantido em confinamento. Rev. Unimar, v.16, p.83-96, 1994.

BAZZOLI, N.; RIZZO, E; SATO, Y. Degeneração ovocitária em curimbatá-pioa Prochilodus affinis (Reinhardt, 1874). In: ENCONTRO DA ASSOCIAÇÃO MINEIRA DE AQUICULTURA, Coletânea de Resumos, 1982-87, Brasília. Anais... Brasília: CODEVASF, 1988. p.99. (Resumo).

BRITSKI, H.A.; SATO, Y.; ROSA, A.B.S. Manual de identificação de peixes da região de Três Marias: com identificação para peixes da bacia do São Francisco. Brasília. Câmara dos Deputados CODEVASF, 1984. p.143. 1984.

FENERICH-VERANI，N.; NARAHARA，M.Y.; GODINHO, H.M. The size composition of eggs of curimbatá Prochilodus scrofa, Steind., 1881, induced to spawn human chorionic gonodotropin (HCG). Aquaculture, v.42, p.37- 41, 1984.

FOWLER, H.W. Os peixes de água doce no Brasil. Arq. Zool., v.6, p.205-404, 1951.

GURAYA, S.S.; KAUR, S.; SAXENA, P.K. Morphology of ovarian changes during reproductive cycle of the fishes, Mystus lengara (Ham). Acta. Anat., v.91, p.222-260, 1975. 
IBGE (Fundação Instituto Brasileira de Geografia e Estatística). Estatística da Pesca. Rio de Janeiro. v.9, p.12, 1998.

ISEKI, K.K. Variações endócrinas durante o ciclo reprodutivo do pacu, Piaractus mesopotamicus, efeito da manipulação da temperatura e fotofase. 2002. 89f. Tese (Doutorado) - Instituto de Biologia, Universidade de São Paulo, São Paulo).

KUNKEL, H.; FLORES, S. Estructura histológica de los ovarios de Pseudoplatystoma coruscans (AGASSIZ, 1829). Pimelodidae, Siluriformes. Bol. Inst. Pesca, v.23, p.203-212, 1996.

LEE, W.K.; YANG, S.W. Relationship between ovarian development and serum levels of gonadal steroids hormones, and induction of oocyte maturation and ovulation in the cultured female Korean spotted sea bass Lateobrax maculatus. Aquaculture, v.207, p.169-183, 2002.

LEONARDO, A.F.G.; ROMAGOSA, E.; BORELLA, M.I. et al. Induced final maturation of hatchery raised Pseudoplatystoma fasciatum (Linnaeus, 1766). Aquaculture, v.240, p.451-461, 2004.

MIRANDA, A.C.L.; BAZZOLI, N.; RIZZO, E. et al. Ovarian follicular atresia in two teleost species: a histological and ultrastructural. Tissue \& Cell, v.31, p.480-488, 1999.

MIRANDA, A.C.L.; RIZZO, E.; BAZZOLI, N. Duração da atresia folicular em Leporinus reinhardit em condições experimentais. In: ENCONTRO BRASILEIRO DE ICTIOLOGIA, 11, 1995, Campinas, São Paulo. Anais... Sociedade Brasileira de Ictiologia, 1995. p.4. (Resumo).

MUNRO, A.D.; SCOTT, A.P.; LAM, T.J. Reproduction seasonal in teleosts: environmental influences. London: CRC, 1990. 254p.

MYHRE, J.L.; DE PAOLI, A.A. glycol methacrylate method for the routine histologic evaluation of rat inner ear. Stain Technol., v.60, p.63-68, 1985.

RESENDE, E.K; CATELLA, A.C.; NASCIMENTO, F.L. et al. Biologia do curimbatá (Prochilodus lineatus), pintado (Pseudoplatystoma corruscans) e cachara (Pseudoplatystoma fasciatum) na bacia hidrográfica do rio Miranda, Pantanal do Mato Grosso do Sul, Brasil, Corumbá, MS. EMBRAPA - CPAP, Boletim de Pesquisa 02, 1995. 75p
ROMAGOSA, E. Desenvolvimento gonadal (morfología: ultra-estrutura) e indução da reprodução do matrinxã, Brycon cephalus (Gunther, 1969) em cativeiro. 1998. 221f. Tese (Doutorado) - Universidade Federal de São Carlos, São Carlos.

ROMAGOSA, E.; LEONARDO, A.F.G.; ARRUDA, R.R. Selection of females of the cachara, Pseudoplatystoma fasciatum (Pisces, Teleostei) to induced spawning In: AQUACULTURE AMÉRICA, 2002. San Diego, 2002. p.286. (Resumo).

ROMAGOSA, E.; NARAHARA M.Y.; BORELLA, M.I. et al. Seleção e caracterização de fêmeas de matrinxã, Brycon cephalus, induzidas a reprodução. Bol. Inst.Pesca, v.27, p.113-121, 2001.

ROMAGOSA, E.; PAIVA, P. de; GODINHO, H. M. Características morfométricas e crescimento do cachara, Pseudoplatystoma fasciatum (Linnaeus, 1766), em cativeiro. Acta Scient., v.25, p.277-283, 2003.

ROMAGOSA, E.; PAIVA, P.; GODINHO. H.M. Pattern of oocyte diameter frequency distribution in females of the pacu, Piaractus mesopotamicus (Holmberg, 1887) (Colossoma mitrei Berg, 1895) induced to spawn. Aquaculture, v.86, p.105-110, 1990.

SHANBHAG, B.A.; SAIDAPUR, S.K. Atretic follicles and corporea lutea in the ovaries of fishes: structure-function correlations and significance. In: MUNSHI, J. S. D.; DUTTA, H. M. (Eds.) Fish morphology horizon of the new research. Rotterdam: Brookfield, 1996, p.146-168.

WEST, G. Methods for assessing ovarian development in fishes: a review. Aust. J. Mar. Freshw. Res., v.41, p.199-222, 1990.

ZANIBONI-FILHO, E.; NUÑER, A.P.O. Reprodução de peixes migradores de água doce. In: CYRINO, J.E.P.; URBINATI, E.C.; FRACALOSSI, D.M. et al. Tópicos especiais em piscicultura de água doce tropical intensiva. São Paulo, 2004. p.45-74.

ZOHAR, Y.; MYLONAS, C.C. Endocrine manipulations of spawning in cultured fish: from hormones to genes. Aquaculture, v.197, p.99-136, 2001. 